\title{
News Consumption Behavior of Young Adults in Malaysia
}

\author{
Karen Sabina Freeman
}

\begin{abstract}
News consumption has been undergoing massive changes due to advances of digitization. In this context, analyzing readers' consumption behavior is pertinent. This study explores the news consumption behavior of young adults in Malaysia. The methodology is based on a quantitative survey of college students, $18-24$ years $(\mathrm{N}=500)$. The results reveal that the majority of the young adults prefer online news instead of traditional news media. Data shows that young adults prefer entertainment news and dislike business and finance news. Findings also highlight that news media consumption appears significantly higher among older youth and males compared to younger youth andfemales. These findings suggest the profound changes of emerging news consumption behavior among young adults andits impact on online news media.
\end{abstract}

Index Terms-Online news, traditional media, young adults.

\section{INTRODUCTION}

Many scholars have been perplexed with young adults' dwindling interest in news and their distaste for print newspaper in particular. Given that young adults are the leading indicators of a country who will guide a country and the world for decades to come, hence, keeping themselves informed and abreast of news and information is vital in making informed decisions.

It appears as if a growing number of people today ignore the information opportunities given to them [1]. In fact the younger generation is losing interest in reading news [2], [3] Rogers [4] proposes that mass media coverage of a certain important issue or topic can stimulate interpersonal communication among people which may in turn influence behavior. Therefore, if young adults are not consuming the news, this will have a huge impact on the news media, in particular the traditional news media. And, if young adults do not consume news, they could be affected as news stimulates interpersonal communication among people.

This study focuses on three main objectives:

- To investigate whether young adults in Malaysia are interested in reading the news.

- To find out the types of news that young adults in Malaysia are looking for.

- To determine which media young adults in Malaysia get most news from.

\section{LITERATURE REVIEW}

Most research of young adults' news consumption habits

Manuscript received December 20, 2012; revised February 20, 2013. Karen Sabina Freeman is with the Faculty of Business, Communication and Law INTI International University, Malaysia (e-mail: karen.freeman@newinti.edu.my). has focused on newspapers. These studies confirm that there is a decline in readership among youths.

American young adults are less likely to engage themselves with the news, be it the traditional media or new media [5]. In fact, journalists and scholars in the United States have been concerned with the dual troubles of young adults' dwindling interest in news and their lack of interest especially in print newspapers [3]. In 1972, roughly $50 \%$ of all college aged adults read a newspaper every day, but it decreases to $20 \%$ in 2008 and keeps dropping among those between 18-29 years. A report from the Kennedy School of Government's Shorenstein Center on the Press, Politics and Public Policy in 2007 found that only one in 20 teens (12-17 years) and one in 12 young adults (18-30 years) read a newspaper on a daily basis.

International Business Machines Corporation's (IBM) international survey among 3,327 respondents found that online news consumption had dropped among those aged 18-24 years, but had risen among older consumers over 55 years [6]. Further, a survey by IBM's Media and Entertainment grouprevealed that $64 \%$ of respondents read a newspaper online in 2008, but by 2009 that figure fell to $54 \%$.

In fact, audience ratings for the main evening news programs on TV are declining throughout the United States and Europe, and newspaper readership among young adults in Europe is declining [1]. Spanish young adults do not read newspapers buthave preferences for other media [2].The reach for German newspapers for all age groups declined from 2006-2010, while, newspaper readership in Italy among young adults was $8.6 \%$ in 2010 [7]. In UK, news consumption rose by $20 \%$ from $2006-2009$, but it comprised online news consumers aged 25-34 years [8].

A study by the World Association of Newspapers [4] reveals that youth view the internet as their first choice for news and information. The fact is online news is abundant and easily available and people go for online news rather than the traditional media [9]. However, research in 2011 [4] found that TV news consumption is higher than online media and that TV is also the most credible media for youth. In addition, $40.8 \%$ of Malaysian youth do not expose themselves to news on the internet and $27.4 \%$ report that they do not consume news on the internet.

In a 2007 poll [10], Australian youth $(53.5 \%)$ selected TV as the main source of news and information, followed by newspapers $(20.5 \%)$ and radio $(16 \%)$. The study by Lancaster, Hughes and Spicer (2012), shows that TV news still remains the major source of news for youth (53.3\%) however, online news (47.9\%) ranked second.

Another survey of youth in Hong Kong revealed that $42 \%$ watch TV for news and current affairs followed by $36 \%$ for newspapers [11]. 
Age is one of the factors that influence the news platform preferences of people. Those 55 years and older prefer newspapers, 37-55 years prefer TV and those below 36 years go online for news and information [12].

In addition, gender is another factor that determines news consumption. In Europe, males consume more news than females, regardless of the format [1], [2]. At the same time, males are more likely to be online news readers compared to females. In the United States, males are more likely to access the new media when looking for news about science issues, whereas females concentrate on newspapers and TV [13]. In fact, males predominate in the use of social networks as well as mass media websites for news gathering [5], [14].

Young adults in the 21 st century are less inclined than their parents or grandparents to read newspapers and less interested in public affairs or to participate politically [12]. Young, urban consumers in China pay more attention to entertainment-based media programs and neglect the information-based media programs such as news programs [15].

A survey by Reuters discloses the different levels of interest in various types of new across UK, United States, Germany, France and Denmark. The British are more interested in celebrity news and less interested in news about the country. Germans are more interested in regional and international news, while Americans are more focused on local news about their town or city and news about the economy. The Danish show the strongest interest in international news while those in the UK and US show the least interest [16].

\section{THEORETICAL FRAMEWORK}

The Uses and Gratifications Theory is grounded in the idea that users have reasons for selecting certainmedia and intentionally choose a message source that best fits their personal needs. This theory assumes that audiences are active with goal-driven media usage and the media possesses the ability to fulfill users' needs. This audience-centered approach says that audiences actively seek out specific media to gratify their needs and desires such as cognitive needs, affective needs, personal integrative needs, social integrative needs and tension free needs [10].

Methodology and Results:

Thesample of 500 youth is from two universities in Malaysia. The data was obtained from randomly distributed questionnaires which comprised 45 questions including the demographic variables. The questionnaire is adapted from the Princeton Survey Research Associates and comprises four sections.

The first section of the questionnaire investigates the interest level in reading news. The second section delves into the types of news that young adults look for. The next section focuses on determining which media young adults get most news from and the last section looks at where they get most news from.

The first objective of this study is to investigate if young adults in Malaysia are interested in reading news. Results show that $68 \%$ of respondents do not read any daily newspaper regularly, $70.6 \%$ do not consume magazines news, $55.6 \%$ do not watch any TV news program regularly and $58 \%$ do not listen to radio news. Nevertheless, $62.4 \%$ of respondents state that they read online news regularly. Meanwhile, data shows that $67.2 \%$ do not follow the news closely most of the time and $5.4 \%$ choose not to follow the news closely most of the time, however, $77.2 \%$ will follow the news closely only when something important or interesting is happening.

Data shows that $79.6 \%$ of respondents havean interest in reading the news. However, $47.2 \%$ feel that it will not make much difference if they read the news. Meanwhile, $36.4 \%$ reveal that they will somewhat miss the news and $12 \%$ will miss the news a lot if they do not have an opportunity to start their day reading the news.

Furthermore, $24.1 \%$ of the 18 -year-old respondents and $34.6 \%$ of the 24 -year-olds reported that they read daily newspapers regularly. Meanwhile, $24.1 \%$ of 18 -yearold respondents and $19.2 \%$ of 24 -year-olds reported that they read magazine news regularly. In addition, $37.2 \%$ of the 18 -year-olds and $46.2 \%$ of the 24-year-oldsreport that they watch TV news programs regularly. About $33.8 \%$ of 18 -year-old respondents and $42.3 \%$ of 24 -year-olds reported that they listen to radio news regularly. Up to $60.7 \%$ of 18 -year-olds and $65.4 \%$ of 24 -year-olds reported that they read online news regularly. Apart from magazines, the older youth (24 years) consume more of all types of media for news than the younger youth (18 years).

Meanwhile, more than $55 \%$ of respondents in all age ranges say they follow the news closely only when something important or interesting is happening.

Findings also show that more males read newspapers, watch TV news, listen to radio news and go online for news than females. However, females consume more magazine news. In fact, $82.7 \%$ of males and $76.6 \%$ of females agree that they are interested in reading news. In comparison to males $(73.4 \%)$, more females $(81 \%)$ reveal that they follow the news closely only when something important or interesting is happening.

The second objective of this study is to find out the types of news that young adults in Malaysia are interested in. Results show that $39 \%$ of respondents follow entertainment news very closely regardless of the media and $48.2 \%$ are interested in news about people and events in their own community. In contrast, $66.2 \%$ are not interested in news about business and finance.

Data analysis of respondents' interest in news topics according to age, reveal that $40.7 \%$ of 18 -year-old respondents follow entertainment news very closely followed by crime news. Meanwhile, 37.9\% of the 19-year-olds follow entertainment news very closely followed by health and science and technology news. Those from 20-24 years follow entertainment news very closely (respectively $43.7 \%, 36.4 \%, 39.2 \%, 33.3 \%$ and $30.8 \%$ for each age group) followed by crime news.

Gender preferences indicate that $32.3 \%$ of males are more interested in following sports news and $31 \%$ entertainment news. They follow somewhat closely local government news $(49.2 \%)$ and news regarding people and events in their community $(46 \%)$. However, they are not interested in religious news, consumer news as well as culture and the 
arts. They are also not at all interested in following news about the weather and business and finance. The females are very interested in entertainment news $(46.8 \%)$ and crime news $(31.3 \%)$, and they follow somewhat closely news about people and events in their community $(50.4 \%)$ and crime news (46\%). However, they are not interestedin political news as well as business and finance news.

The final research objective is to determine which media young adults in Malaysia get most news from and where the respondents are accessing most of their news. Results show that $61.6 \%$ choose the Internet as the most often used source of news, while $42.2 \%$ selected magazines as their least used source of news. The top three media the respondents use are The Star Online, followed by Google.com and The Star Newspaper.

\section{DISCUSSION}

Overall young adults in Malaysia are fairly intensive users of online news sites as more than half of the respondents read online news regularly. The age group that regularly reads more online news is the 21-24 year old young adults, while those between 18-20years utilize less online news.

The older age group also shows more interest in news. Findings reveal that the older young adult age group consumes more news from almost all media regularly compared to the younger group. Studies show that with age people consume more news and show more interest in news [2], [4], [10].

In terms of the types of news that Malaysian young adults are interested in, this study again compared the youngest and oldestage groups. Data shows that the 18-year-olds follow entertainment news very closely and crime news, while the 24-year-olds follow news about entertainment very closely, crime and newsa bout people and events in their community. This result is similar to the survey of young people in UK [17].

This study also found that males are more interested in the news than females. However, more females consume magazine news compared to males. The findings show that males are more likely to follow the news closely most of the time, while more females follow the news only when something important is happening.

The number of males following sports news, political news, business and finance news as well as science and technology news is approximately double the number of females. Females consume more news about people and events in their community, entertainment, crime, culture and the arts, as well as weather news. These results are somewhat similar to findings of a survey in UK. This similarity shows that the types of news that young adult males and females are interested in are relatively the same [17].

In general, young adults in Malaysia are more interested in entertainment news, while they are indifferent to business and finance news, and political news. This is consistent with the Uses and Gratifications Theory where people actively look for information to satisfy their needs and desires.

There are four million Malaysian eligible voters who have not registered with the Malaysian Election
Commission (EC) and two-thirds of them are between 22-30 years [18]. This shows that young adults in Malaysia are not interested in political news and this corresponds with the findings of this study.

As for business and finance news, perhaps one of the reasons why Malaysian young adults are not interested could be attributed to the high unemployment rate in Asia. The youth unemployment rate has remained high since the Asian financial crisis struck in 1998. It roseto $11.3 \%$ in 2010 from a low of $6.7 \%$ in 1996. In addition, approximately 75 million young adults worldwide are without jobs. The global youth unemployment rate has remained at $12.6 \%$ for the past three years [19]. It is possible that young adults feel frustrated and entertainment news is highly consumed as itoffersrelief and escapism from the reality of everyday life.

In addition, the results of this study found that most Malaysian young adults choose the internet as their main source of news. These results are contrary to the findings of Saodah Wok, Ezhar Tamam, Jusang Bolong and Abdul Mua'ti@Zamri Ahmad (2011) [4] which found that TV news consumption is highest among youth in Malaysia. Similarly, the majority of young adults in Hong Kong watch TV for news and current affairs (Chan \& Fang, 2007)[11] and as indicated in the 2007 Roy Morgan poll showing that TV is the main source of news and information for Australian youth (Lancaster, Hughes \& Spicer, 2012) [10]. However, a study from the World Association of Newspapers [4] reveals that youth today view the internet as their first choice for news and information.

The Uses and Gratifications theory supports these findings as young adults are a heterogeneous audience, and the effect of ageand gender are factors that influence the interest and usage of the news media. Young adults are not passive audiences. They make active media choices particularly about the type of news and media they prefer to access.

While newspaper readership is on a decline among young people, the data of this study show that Malaysian young adult's news consumption is oriented towards the digital media, especially internet websites and social networks. This shows that their appetite for news has not diminished, quite the contrary, interest in news and information is fairly high. Further, this study finds that news consumption and interest in news among young adults in Malaysia increases with age and maturity.

Ultimately, this study advances an understanding of Malaysian young adults' preference for online news and in particular entertainment news. This raises the need for online media to address the complexity of online news being entertaining while keeping young adults informed.

\section{REFERENCES}

[1] A. Blekesaune, A. Elvestad, and T. Aalberg, "Tuning out The World of News and Current Affairs-An Empirical Study of Europe's Disconnected Citizens," European Sociological Review, vol. 28, no. 1, pp. 110-126, 2012.

[2] A. C. Ripolles, "Beyond Newspapers: News Consumption among Young People in the Digital Era," Scientific Journal of Media Education, vol. 39, pp. 151-158, 2012.

[3] S. C. Lewis, "Where Young Adults Intend To Get News In Five Years," Newspaper Research Journal, vol. 29, no. 36-52, 2008. 
[4] S. S. Wok, E. Tamam., J. Bolong, and A. M. @ Z. Ahmad, "Pattern of News Media Consumption and News Discussion among Youth: A Test of Agenda Setting Theory," Global Media Journal, vol. 1, no. 1, pp. 1-31, 2011.

[5] H. I. Chyi and A. M. Lee, "Theorizing Online News Consumption: A Structural Model Linking Preference, Use, and Paying Intent," Online Journalism, pp. 1-29, 2012.

[6] D. Benkoil. (2010). Young Online Newspaper Audience Groping; Older Consumers Adopting Social Media. [Online]. Available: http://www.poynter.org/how-tos/digital-strategies/e-media-tidbits/100 328/young-online-newspaper-audience-dropping-older-consumers-ad opting-social-media/.

[7] World Press Trends. (2012b). Retrieved November 26, 2012. [Online]. Available:

http://www.wan-ifra.org/articles/2012/09/03/world-press-trends.

[8] M. Kinsey. (2010). A glimmer of hope for newspapers. [Online]. Available:

http://www.newspaperdeathwatch.com/wp-content/uploads/2010/04/ Glimmer_of_hope_for_newspapers.

[9] D. Mehrabi, M. A. Hassan, and M. S. S. Ali, "News Media Credibility of the Internet and TV," European Journal of Social Science, vol. 11, no. 1, pp. 136-148, 2009.

[10] K. Lancaster, C. E. Hughes, and B. Spicer, "News Media Consumption among Young Australians: Patterns of Use andAttitudes towards Media Reporting," Peer Reviewed Journal, vol. 143, pp. 16-27, 2012.

[11] K. Chan and W. Fang, "Use of the Internet and Traditional Media among Young People," Research Paper, vol. 8, no. 4, pp. 244-256, 2007.

[12] I. Bachmann, K. Kaufhold, S. C. Lewis, and H. G. D. Zuniga, "News Platform Preference: Advancing the Effects of Age and Media Consumption on Political Participation," International Journal of Internet Science, vol. 5, no. 1, pp. 34-47, 2010.

[13] A. A. Anderson, D. Brossard, and D. Scheufele, "The Changing Information Environment for Nanotechnology: Online Audience and
Content," Peer Reviewed Journal, vol. 12, no. 4, pp. 1083-1094, 2010

[14] P. Poindexter, S. Meraz, and A. S. Weiss, Women, Men, and News: Divided and Disconnected in the News Media Landscape, NY: Routledge, 2008.

[15] W. Dou, G. Wang, and N. Zhou, "Generational and Regional Differences in Media Consumption Patterns of Chinese Generation X Consumers," Journal of Advertising, vol. 35, no. 2, pp. 101-110, 2006.

[16] N. Newman. (2012). Reuters Institute Digital News Report. [Online]. Available:

http://reutersinstitute.politics.ox.ac.uk/fileadmin/documents/Publicati ons/Other_publications/Reuters_Institute_Digital_Report.pdf.

[17] Ofcom. (2007). Annexes to New News. Future News: Research and Evidence Base. [Online]. Available: http://stakeholders.ofcom.org.uk /binaries /research/tv-research/newnewsannexes.pdf.

[18] S. A. Rahmin, L. Pawanteh, and A. Salman, "Citizenship Norms and the Participation of Young Adults in a Democracy," World Academy of Science, Engineering and Technology, vol. 64, pp. 387-391, 2012.

[19] M. Mazlan. (2012). Challenging times for the young. [Online]. Available:

http://www.nst.com.my/opinion/columnist/challenging-times-for-theyoung-1.111741.

Karen Sabina Freeman holds a B.Sc. in Mass Communication from Northwest Missouri State University, USA, a M.Ed. in Psychology from the University of Malaya, and a Professional Certificate in Public Relations. She teaches media and communication courses and is currently a Senior Lecturer at INTI International University, Malaysia. Karen has held various academic management roles specifically in coordinating and managing transfer/twinning degree programs in Malaysia. Prior to joining academia, she worked as a journalist with various publications in USA, Singapore and Malaysia, and then as a corporate communications consultant in Kuala Lumpur. 